\title{
The Level of Practicing Safe Sex among Athletes in Malaysia to Prevent AIDS
}

\author{
Vincent A. Parnabas \\ Faculty of Sport Science and Recreation, Universiti Teknologi MARA (UiTM), Shah Alam, 40450 Selangor, Malaysia \\ *Corresponding Author: vincent@salam.uitm.edu.my
}

Copyright (C) 2014 Horizon Research Publishing All rights reserved.

\begin{abstract}
The use of condoms is one of the safer sex practices to prevent AIDS, since it creates a barrier between the semen and the internal tissue that collect the semen and prevent it from entering into the sexual partner's body. It is very important to evaluate the level of knowledge on AIDS and awareness of prevention among athletes since they can be the most risky population since frequently travels to overseas and other countries for sports competition. The purpose of this study was to evaluate the knowledge of AIDS and the awareness to prevent it by practicing safe sex, among athletes from different skills. The sample consisted of 137 athletes, with national $(\mathrm{N}=78)$, state $(\mathrm{N}=31)$, district $(\mathrm{N}=17)$ and university $(\mathrm{N}=11)$ skill athletes. Those athletes involved in ASEAN University Games (AUG), Laos, in 2012. HIV/AIDS Questionnaire, which consists 29 items was used in this study. The result showed that the willingness to associate with HIV/AIDS-infected person, interest in HIV/AIDS educations, the knowledge of HIV/AIDS transmission modes and understanding HIV/AIDS risk behavior, was higher on national level athletes compared to other categories. However no significance difference was found on the willingness to practice safe sex among different skill athletes. Furthermore, the level of willingness to practice sex was lower among all the skill categories. Sport psychologist, coaches and condom companies in Malaysia can use the result of this study to promote condoms to all skilled athletes to prevent AIDS. Elements that promote strategy of condoms among athletes are advertising, publicity, activities and inducements in sports event, public relations, personal selling and sponsorship.
\end{abstract}

Keywords AIDS, HIV, Safe Sex, Condom

\section{Introduction}

The term HIV and AIDS are mostly understood in the framework of biomedical concepts. In essence, it refers to a specific intrusion virus; human immune deficiency virus (HIV) in the body that can cause the body to lose the natural defense mechanism to against the assault from disease-causing agents (Riji \& Pataki-Schweizer, 2002). HIV or known as 'Human Immunodeficiency Virus' is a virus that commonly effect the human beings only and it will weaken the human immune system by eliminating the important cell that fight the disease and infection (Riji \& Pataki-Schweizer, 2002). Acquired Immune Deficiency Syndrome is the final stage of HIV infection (Green \& Sobo, 2000). Victims at this stage of HIV disease have badly damaged immune system, which puts them at risk for opportunistic infections (Gomez, Clark, Moore, Nolan, Thomas, Vanderlan, Samplin-Salgado, LeBel, Baker, Badaczeski, T., Anderson, J., Nichamin, M., DeLoose, Ray, Robert, Nolan, Dang, Bush, Joseph, Cozier \& Gruse, 2012). 1). A lack of this immune system cannot protect the body from disease. This is because these viruses can breed by itself by taking over a cell virus in the body of their host.

Sexual relationship with sex workers or known as prostitutes will increase the risk due to the sexual intercourse that the prostitutes had with their client. The presences of other sexually transmitted diseases (STD) reject a higher risk, such as cuts and sores from HIV entry permit. Epidemiological studies showed that vaginal intercourse allows transmission of HIV and oral genital contact can become a risky practice as well (Weeks \& Alcamo, 2010). Anal intercourses involve the highest risk for tearing and haemorrhage the rectal tissue that will allow HIV access to the blood stream.

HIV prevention services are increasingly used by individuals in developing countries, yet we know very little about how self-assessed HIV risks determine the health seeking behaviors. People may feel that they are at risk of HIV infection for many reasons such as the behavior of both the risks and concerns associated with increased HIV awareness.

Mostly have said that contact with HIV through sexual activity with infected person must be avoided, but this suggestion is not realistic for many people. In order to prevent the spread of AIDS, public health officials are trying their best to encourage the modifications of sexual behaviors, which is also known as safe sex practices.

Whatever that creates a barrier between the semen and the internal tissues of sexual partners may reduce the risk of HIV 
infection. The use of condoms is one of the safe sex practices, because condoms create a barrier between the semen and the internal tissue which will collect the semen and prevent it from entering the sexual partner's body (Weeks \& Alcamo, 2010). This condom is soft, stretchable sheath placed over the penis during sexual intercourse, whether vaginal, oral or anal. Extensive studies have demonstrated conclusively that condoms can decrease the risk of STDs, including HIV infection, by decreasing the transmission of infectious agents. In 1993, for example, the Centers for Disease Control and Prevention (CDC) reported that HIV fail to be transmitted among 123 couples who used condoms when one person was infected (Weeks \& Alcamo, 2010).

Condoms reduced the risk of HIV infection for both the wearer and his sexual partner (Weeks \& Alcamo, 2010). Latex condom is reliable and more effective compared to natural skin condom because they are thick and quality control standards. For personal protection, finest, a condom must been worn in every sexual encounter.

A condom creates a barrier between the sperm and the internal tissues of sexual partners and reducing the risk of HIV infection (Weeks \& Alcamo, 2010). Condoms are placed upon an erection reached.

Condoms implemented directly into the penis, leaving a reservoir to catch semen.

Even though condom has been proven the best method to prevent AIDS but not many factories, find an effective way to promote it. Therefore it fails to reach the target population. Therefore AIDS infections are increasing gradually specially among Malaysians. The below data showed that the increase of HIV infections, AIDS cases and AIDS death from 1986 to 2008 in Malaysia (Malaysian AIDS Council, 2009).

Even though not many researches done on the knowledge of AIDS and awareness of preventing it among athletes, but athletes can be the most risky categories, can be affected by this incurable disease since many athletes believe sex before sport competition can enhance their performance. In fact, some studies suggest that pre-sports sex may actually aid athletes by raising their testosterone levels (Lovgren, 2010). Furthermore, according to Shrier, a sports medicine specialist at McGill University in Montreal, Canada, sex before competition could affect athletes' psychological state of mind. In fact, according to (Leach, 2002.) in future there will be more athletes suffer from AIDS.

Table 1. No. of new hiv infections, aids cases and aids deaths by gender per year reported in malaysia (from 1986 until december 2008)

\begin{tabular}{|c|c|c|c|c|c|c|c|c|c|}
\hline \multirow{2}{*}{ YEAR } & \multicolumn{3}{|c|}{ HIV INFECTION } & \multicolumn{3}{|c|}{ AIDS CASES } & \multicolumn{3}{|c|}{ AIDS DEATH } \\
\hline & Male & Female & TOTAL & Male & Female & & Male & Female & TOTAL \\
\hline 1986 & 3 & 0 & 3 & 1 & 0 & 1 & 1 & 0 & 1 \\
\hline 1987 & 2 & 0 & 2 & 0 & 0 & 0 & 0 & 0 & 0 \\
\hline 1988 & 7 & 2 & 9 & 2 & 0 & 2 & 2 & 0 & 2 \\
\hline 1989 & 197 & 3 & 200 & 2 & 0 & 2 & 1 & 0 & 1 \\
\hline 1990 & 769 & 9 & 778 & 18 & 0 & 18 & 10 & 0 & 10 \\
\hline 1991 & 1741 & 53 & 1794 & 58 & 2 & 60 & 10 & 9 & 19 \\
\hline 1992 & 2443 & 69 & 2512 & 70 & 3 & 73 & 44 & 2 & 46 \\
\hline 1993 & 2441 & 66 & 2507 & 64 & 7 & 71 & 50 & 5 & 55 \\
\hline 1994 & 3289 & 104 & 3393 & 98 & 7 & 105 & 74 & 6 & 80 \\
\hline 1995 & 4037 & 161 & 4198 & 218 & 15 & 233 & 150 & 15 & 165 \\
\hline 1996 & 4406 & 191 & 4597 & 327 & 20 & 347 & 259 & 12 & 271 \\
\hline 1997 & 3727 & 197 & 3924 & 538 & 30 & 568 & 449 & 24 & 473 \\
\hline 1998 & 4327 & 297 & 4624 & 818 & 57 & 875 & 655 & 34 & 689 \\
\hline 1999 & 4312 & 380 & 4692 & 1114 & 86 & 1200 & 824 & 50 & 874 \\
\hline 2000 & 4626 & 481 & 5107 & 1071 & 97 & 1168 & 825 & 57 & 882 \\
\hline 2001 & 5472 & 466 & 5938 & 1188 & 114 & 1302 & 900 & 75 & 975 \\
\hline 2002 & 6349 & 629 & 6978 & 1068 & 125 & 1193 & 823 & 64 & 887 \\
\hline 2003 & 6083 & 673 & 6754 & 939 & 137 & 1076 & 633 & 67 & 700 \\
\hline 2004 & 5731 & 696 & 6427 & 1002 & 146 & 1148 & 951 & 114 & 1065 \\
\hline 2005 & 5383 & 737 & 6120 & 1044 & 177 & 1221 & 882 & 102 & 984 \\
\hline 2006 & 4955 & 875 & 5830 & 1620 & 222 & 1842 & 896 & 80 & 976 \\
\hline 2007 & 3804 & 745 & 4549 & 937 & 193 & 1130 & 1048 & 131 & 1179 \\
\hline 2008 & 2988 & 704 & 3692 & 795 & 146 & 941 & 786 & 114 & 900 \\
\hline TOTAL & 77,092 & 7,538 & 84,630 & 12,992 & 1,548 & 14,576 & 10,273 & 961 & 11,234 \\
\hline
\end{tabular}


Condom product industries in Malaysia, like Karex and Nulatex, should promote their product to athletes to prevent AIDS. For example, The International Olympic Committee distributed 150,000 condoms to athletes competing in London in 2012, since believed that sex before competition had the tendency to enhance performance (Nieto, 2012).

It is very important to evaluate the level of knowledge on AIDS and awareness of preventing it among athletes since they can be the most risky population sincefrequently traveling to overseasfor sports competitions and believed that sex before competition can enhance their performance. Athletes who married also find it impossible for them to bring their wives along and they might have sex with prostitutes to enhance their performance in sports.

\section{Aim of the Study}

The purpose of this study was to evaluate the knowledge of AIDS and the awareness to prevent it by practicing safe sex, especially the usage of condoms, among athletes from different skills.

\section{Method}

The sample consisted of 137 athletes, with national $(\mathrm{N}=78)$, state $(\mathrm{N}=31)$, district $(\mathrm{N}=17)$, and university $(\mathrm{N}=11)$ skill athletes. Those athletes involved in ASEAN University Games (AUG) 2012, from 12 to 20 December 2012. ASEAN University Games (AUG) is a biennial sports event that involves athletes from the universities of the ASEAN member countries. HIV/AIDS Questionnaire, which consists 29 items was used in this study. The questionnaire was divided into 5 factors. Those factors are willingness to associate with HIV/AIDS-infected person, interest in HIV/AIDS educations, the knowledge of HIV/AIDS transmission modes, the willingness to practice safe sex and understanding HIV/AIDS risk behavior.

\section{Result}

\section{Cronbach Reliability Coefficients}

In this study, Cronbach alpha were found ranging from .75 to .87 . Coefficients of .70 and above were considered reliable. Therefore included in the interpretation of the data (Table 2).

Frequency, Percentage, mean and standard deviation Are presented in Table 3, which shows the overall results of the respondents' profile. The profile of the respondents described the ethnics, gender, age and level of sport performance. There are 78 male and 59 female athletes participated in this study.

Based on the ethnic, the majority of athletes belong to Malays $(56.20 \%)$ since they are the majority race in
Malaysia. The second largest ethnic in Malaysia are Chinese. There are $28.47 \%$ athletes from Chinese ethnic. Indians are the lowest ethnic in Malaysia. There are $15.33 \%$ athletes from Indian ethnic.

Table 2. Cronbach Reliability Coefficients

\begin{tabular}{|c|c|}
\hline HIV/AIDS Questionnaire & $\begin{array}{c}\text { Cronbach's Alpha } \\
(\mathrm{n}=137)\end{array}$ \\
\hline $\begin{array}{c}\text { Willingness to associate with } \\
\text { HIV/AIDS-infected person }\end{array}$ & .8712 \\
\hline Interest in HIV/AIDS educations & .8012 \\
\hline $\begin{array}{c}\text { The knowledge of HIV/AIDS transmission } \\
\text { modes }\end{array}$ & .7527 \\
\hline The willingness to practice safe sex & .8512 \\
\hline Understanding of HIV/AIDS risk behavior, & .7967 \\
\hline
\end{tabular}

The mean age for overall respondents was 22.18 years old. The age of male varied from 19 to 28 years, where the mean age was 21.11 years old. The age of females ranged from the minimum of 18 to the maximum of 27 years old. The mean age for female respondents was 21.12 years old.

The variable "level of sport performance" is gathered through the studies. Based on the level of performance, the majority of the respondents obtain the highest performance in sport, national $(70.80 \%)$. followed by state $(15.33 \%)$,district $(8.76 \%)$ and university level (5.11\%),

Table 3. Profile of the respondents

\begin{tabular}{|c|c|c|c|c|}
\hline Variables & Frequency & Percentage & Mean & SD \\
\hline \multicolumn{5}{|l|}{ Ethnics } \\
\hline Malay & 77 & 56.20 & & \\
\hline Chinese & 39 & 28.47 & & \\
\hline Indian & 21 & 15.33 & & \\
\hline \multicolumn{5}{|l|}{ Gender } \\
\hline Male & 78 & 56.93 & & \\
\hline Female & 59 & 43.07 & & \\
\hline \multicolumn{5}{|l|}{ Age } \\
\hline Male & & & 21.11 & 2.27 \\
\hline Female & & & 21.12 & 1.82 \\
\hline Overall & & & 22.18 & 1.89 \\
\hline \multicolumn{5}{|l|}{$\begin{array}{c}\text { Level of } \\
\text { Performance }\end{array}$} \\
\hline National & 97 & 70.80 & & \\
\hline State & 21 & 15.33 & & \\
\hline District & 12 & 8.76 & & \\
\hline University & 7 & 5.11 & & \\
\hline
\end{tabular}


Table 4. Knowlege of HIV/AIDS and prevention among athletes

\begin{tabular}{|c|c|c|c|c|}
\hline Knowledge of AIDS/HIV & Skills of Athletes & Mean & F-Value & P-Value \\
\hline \multirow{4}{*}{$\begin{array}{l}\text { Willingness to associate with } \\
\text { HIV/AIDS-infected person }\end{array}$} & National & 19.1712 & \multirow{4}{*}{$14.712 * *$} & \multirow{4}{*}{0.000} \\
\hline & State & 16.2567 & & \\
\hline & Distict & 13.1412 & & \\
\hline & University & 12.4561 & & \\
\hline \multirow{4}{*}{ Interest in HIV/AIDS education } & National & 19.7173 & \multirow{4}{*}{$15.551^{* *}$} & \multirow{4}{*}{0.000} \\
\hline & State & 13.2217 & & \\
\hline & Distict & 12.5147 & & \\
\hline & University & 10.6971 & & \\
\hline \multirow{4}{*}{$\begin{array}{l}\text { Knowledge of HIV/AIDS } \\
\text { transmission modes }\end{array}$} & National & 18.7752 & \multirow{4}{*}{$16.412 * *$} & \multirow{4}{*}{0.000} \\
\hline & State & 14.6744 & & \\
\hline & Distict & 12.1361 & & \\
\hline & University & 9.5513 & & \\
\hline \multirow{4}{*}{ Willingness to practice safe sex } & National & 10.2412 & \multirow{4}{*}{10.172} & \multirow{4}{*}{0.712} \\
\hline & State & 9.9789 & & \\
\hline & Distict & 10.2270 & & \\
\hline & University & 9.6742 & & \\
\hline \multirow{4}{*}{$\begin{array}{l}\text { Understanding HIV/AIDS risk } \\
\text { behavior. }\end{array}$} & National & 21.7853 & \multirow{4}{*}{$15.421^{* *}$} & \multirow{4}{*}{0.000} \\
\hline & State & 18.4678 & & \\
\hline & Distict & 14.7815 & & \\
\hline & University & 12.4123 & & \\
\hline
\end{tabular}

$* * \mathrm{p}=.01$

Table 5. Post Hoc Tukey Test: Knowlege of HIV/AIDS and prevention among athletes

\begin{tabular}{|c|c|c|c|c|c|c|}
\hline $\begin{array}{l}\text { Knowledge of } \\
\text { AIDS/HIV }\end{array}$ & Skills of Athletes & National & State & Distict & University & $\mathrm{N}$ \\
\hline \multirow{4}{*}{$\begin{array}{c}\text { Willingness to } \\
\text { associate with } \\
\text { HIV/AIDS-infected } \\
\text { person }\end{array}$} & National & & $*(2.611)$ & *(1.371) & $*(2.711)$ & 78 \\
\hline & State & & & & & 31 \\
\hline & Distict & & & & & 17 \\
\hline & University & & & & & 11 \\
\hline \multirow{4}{*}{$\begin{array}{l}\text { Interest in HIV/AIDS } \\
\text { education }\end{array}$} & National & & *(1.459) & $*(1.681)$ & $*(2.113)$ & 78 \\
\hline & State & & & & & 31 \\
\hline & Distict & & & & & 17 \\
\hline & University & & & & & 11 \\
\hline \multirow{4}{*}{$\begin{array}{c}\text { Knowledge of } \\
\text { HIV/AIDS } \\
\text { transmission modes }\end{array}$} & National & & *(1.783) & $*(1.650)$ & $*(1.371)$ & 78 \\
\hline & State & & & & & 31 \\
\hline & Distict & & & & & 17 \\
\hline & University & & & & & 11 \\
\hline \multirow{4}{*}{$\begin{array}{l}\text { Understanding } \\
\text { HIV/AIDS risk } \\
\text { behavior. }\end{array}$} & National & & $*(1.671)$ & $*(1.221)$ & * (2.997) & 78 \\
\hline & State & & & & & 31 \\
\hline & Distict & & & & & 17 \\
\hline & University & & & & & 11 \\
\hline
\end{tabular}


Table 4 shows the mean scores for the knowledge of AIDS/HIV among the athletes of different skills:

i. Willingness to associate with HIV/AIDS-infected person, $\mathrm{F}(3,137)=14.712, \mathrm{p}=.01$.

ii. Interest in HIV/AIDS educations, $\mathrm{F}(3,137)$ $=15.551, \mathrm{p}=.01$.

iii. The knowledge of HIV/AIDS transmission modes, $\mathrm{F}(3,137)=16.412, \mathrm{p}=.01$.

iv. The willingness to practice safe sex, $F(3,137)$ $=10.172, \mathrm{p}>.05$.

v. Understanding of HIV/AIDS risk behavior, F (3, 137) $=15.421, \mathrm{p}=.01$.

Apparently, significant differences emerged for the athletes having different skills at competition except on the willingness to practice safe sex. Overall, the mean score obtained for the national level athletes was higher than those in other categories.

Post-Hoc Tukey Test (Table 5) showed that the level of willingness to associate with HIV/AIDS-infected person, interest in HIV/AIDS educations, the knowledge of HIV/AIDS transmission modes, understanding of HIV/AIDS risk behavior, of national were higher than district $(p=.05)$, state $(p=.05)$ and university $(p=.05)$ level athletes.

Furthermore, the level of willingness to associate with HIV/AIDS-infected person, interest in HIV/AIDS educations, the knowledge of HIV/AIDS transmission ii modes, understanding of HIV/AIDS risk behavior, of state were higher than district $(p=.05)$, and university $(p=.05)$ but lower than national $(p=.05)$ level athletes.

Post-Hoc Tukey Test also showed that the level of iv. willingness to associate with HIV/AIDS-infected person, interest in HIV/AIDS educations, the knowledge of HIV/AIDS transmission modes, understanding of HIV/AIDS risk behavior, of district were higher than university $(\mathrm{p}=.05)$ but lower than national $(\mathrm{p}=.05)$ and state $(\mathrm{p}=.05)$ level athletes.

Lastly, the level of willingness to associate with HIV/AIDS-infected person, interest in HIV/AIDS educations, the knowledge of HIV/AIDS transmission modes, understanding of HIV/AIDS risk behavior, of university were lower than district $(\mathrm{p}=.05)$, state $(\mathrm{p}=.05)$ and national $(\mathrm{p}=.05)$ level athletes.

\section{Discussion}

The result showed that the willingness to associate with HIV/AIDS-infected person, interest in HIV/AIDS educations, the knowledge of HIV/AIDS transmission modes and understanding HIV/AIDS risk behavior, was higher on national level athletes compared to other categories. Furthermore, the result showed that there is no significance difference on the willingness to practice safe sex among the skill of athletes. Overall, the mean for practicing safe sex is very low among all the four (4) skills categories of the athletes. It showed that athletes still not able to practice safe sex, especially using condoms even though they understand the risk of having sex without protection. For personal protection, a condom must be worn in every sexual encounter. Condoms reduce the risk of HIV infection for both the wearer and his sexual partner (Weeks \& Alcamo, 2010). Latex condom is reliable and more effective compared to natural skin condom because they are thick and quality control standards. The condoms prevent semen from entering the vagina, anus or mouth. It also prevents vaginal fluids from coming into contact with the penis. The increase number of HIV infections, AIDS cases and deaths (Table 1) and the low level of willingness to practice safe sex (Table 2) showed that the knowledge of prevention of AIDS using condoms still fail to reached many people. Condom companies, sport psychologist and coaches in Malaysia should play an important role to promote condoms to all skill categories of athletes to prevent AIDS. Elements that compose promotion strategy of condoms among athletes are (Pederson, Parks, Quarterman \& Thibayult, 2011.):

i. Advertising. Promote the importance of wearing condoms in newspapers, sportsmagazines, sports programs of TV and radio, sports websites, sports arena, game programs and sports posters.

ii. Publicity.Condom product companies should use TV and radio, to advertise the effect of condoms from preventing AIDS disease.

Activities and inducements in sports event. Promotion can be conducted at the sports events to purchase condoms by giveaway product samples, contest and so on.

Public relations. Activities and programs, especially those associated with athletes and media relations to promote the use of condoms. This will help the condom companies to develop positive relationship with athletes, the target group. For example, through the AIDS campaign, the Karex and Nulatex seeks to communicate the importance of using condoms to public relation activities that promote the awareness of AIDS and the need for athletes to take an active role in preventing it.

v. Personal selling. Direct face to face communication with athletes to sell condoms. Personal selling is unique and highly effective because it allows sales personals to adapt messages based on feedback, communicate more information to the athletes, guarantee that the athletes will pay attention to the messages being derived and develop a long-term relationship with the athletes.

vi. Sponsorship. Sponsorship is a form of promotion that involves a partnership between condom product companies and sports organization. Business partnerships are based on exchange theory. Condom companies provide money or services to the sports organization or event and in return sports organization used various designations or phrases in connection with condoms, such as "official sponsor by Karex" or "presented by Nulatex'. 


\section{Conclusion and Recommendation}

The result showed that the willingness to associate with HIV/AIDS-infected person, interest in HIV/AIDS educations, the knowledge of HIV/AIDS transmission modes and understanding HIV/AIDS risk behavior, was higher on national level athletes but lower on the willingness to practice safe sex. Overall, all the skill categories of athletes showed a very low level of willingness to practice safe sex. Since condoms considered as the only method to prevent AIDS/HIV or safe sex, condom companies in Malaysia should play an important role to promote it. The prevention of AIDS among athletes depends on the usage of condoms. Condom companies in Malaysia should use this result to play an important role in promoting condoms to all skilled athletes. Elements that compose promotion strategy of condoms among athletes are advertising, publicity, activities and inducements in sports event, public relations, personal selling and sponsorship.

\section{REFERENCES}

[1] Gomez, M., Clark, M., Moore, A., Nolan, J., Thomas, C., Vanderlan, J., Samplin-Salgado, M., LeBel, D., Baker, P., Badaczeski, T., Anderson, J., Nichamin, M., DeLoose, C., Ray, N., Robert, B., Nolan, R., Dang, V. K., Bush, A., Joseph, R., Cozier, N., \&Gruse, G. (2012). What ishiv/aids?
Retrieved 10/02/2013, from U.S. Department of Health and Human Services: http://www.aids.gov/hiv-aids-basics/hiv-ai ds-101/what-is-hiv-aids/

[2] Green, G., \& Sobo, E. J. 2000.The endangered self managing the social risks of HIV. UK: Taylor and Francis Group.

[3] Malaysian AIDS Council. 2009. AIDS/STI Unit. Ministry of Health Malaysia. (http://www.ptfmalaysia.org/statistic.htm).

[4] Leach, L. 2002. HIV/AIDS and sport.Science in Africa: Africa's first online science magazine http://www.scienceinafrica.co.za/2003/february/sport.htm.(2 8 July 2007).

[5] Lovgren, S. 2010. Sex and Sports: Should Athletes Abstain Before Big Events? National Geographic News. (http://news.nationalgeographic.com/news/2006/02/0222_06 0222_sex.html).

[6] Nieto, A. J. 2012. Sex before competing: Does it boost athletes' performance? CNN(http://edition.cnn.com/2012/08/ 10/health/sex-athletes).

[7] Pederson, P.M., Parks, J. B., Quarterman, J.\&Thibayult, L. 2011. Contemporary Sport Management. United States: Human Kinetics.

[8] Riji, H. M., \& Pataki-Schweizer, K. J. (2002).Hiv/aids the realities, the challenges. Malaysia: Ministry of Health Malaysia.

[9] Weeks, B., S,.,\& Alcamo, I., E,. 2010. Aids the biological basis (Fifth ed.). Boston: Jones and Bartlett. 